QIJIS: Qudus International Journal of Islamic Studies

Volume 4, Issue 2, August 2016

\title{
MULTICULTURAL EDUCATION IN THE DIVERSITY OF NATIONAL CULTURES
}

\author{
Muhammad Miftah \\ STAIN Kudus, Central Java, Indonesia \\ azza_1455@yahoo.co.id
}

\begin{abstract}
This article tries to explain about the importance of tolerance, respecting the diversities among the society by multicultural education. The diversity of national culture will be lost by the time goes by if it is not supported by Indonesian human resource ability in maintaining and conserving the existing culture. Multicultural education is kawah candradimuka in maintaining the plural cultures to avoid the conflict leading to dispute and split of united Nation of Indonesian Republic (NKRI).
\end{abstract}

Keywords: Education, Multicultural,Diversity, Culture.

\section{A. Introduction}

The existing cultural diversity in our country is one of forms and a evidence where our country is rich of cultures. Every area in Indonesia has its culture and its own characteristic. The diversity and the uniqueness of culture are often meant to be a threat by the society for group of culture in minority. It causes problem in our country which is not done and it is about disharmony in living in a 
country with cultures.

Dispute between majority ethnic and minority ethnic does not only happen in Indonesia. It also has been happening in America since $1990^{\text {th }}$ that the relation between dominant culture and the weaker has aroused conflict, even aggression and against. We often see in both printed and electronic mass media, there are some news informing about children fight, denounce, physic violence (Maliki, 2010: 252). There are some factors which cause violence entrenched in the middle of our society, such as ideology, economy, culture or even certain belief.

If the above problem is analyzed, the anarchy did by a group society to other community is contradicted with the values of Indonesia that is civilized and fair humanity which becomes one of five basic platform of Indonesia (Pancasila). Besides contradicting with Pancasila, it also contradicted with the plurality of religion and culture.

This culture disharmony will become dangerous "Spines civilization" even more dangerous in multicultural society. A certain group could "prey" resident or other citizen community by the name of god, social status, even politic and economy. It is very dangerous. It will ruin not only the basic nationality characters but also disturb democratic process in our country which become prerequirement of forming ultimate civilized society.

As a rich culture country, Indonesia is really prone for dispute among ethnics. Indonesia needs a cure to form a piece, fairness, similarity, freedom and togetherness which can be produced by multicultural education. It is hoped that multicultural education can muffle the conflict in our society, to realize tolerant attitude to respect each other and to be wise in understanding a difference.

\section{B. Multikultural Education}

Multicultural comes from a word "kultur". There are some experts who give the definition. Elizabet B. Taylor (1832-1917) and L.H. Morgan (1818-1881) defines kultur as a universal culture 
for human in several levels which are adopted by all society. While Emile Durkheim (1858-1917) and Marcel Maus (1872-1950) explain that culture is a group of society which adopt binding symbols in society to apply (Hasan, 2000: 159).

Multicultural education see human being widely, it is not only limited on racial side but multicultural education also about unfairness, poverty, oppression, backwardness of minority in various sides; social, culture, economy, education and etcetera (Mahfud, 2006: 179).

Principally, multicultural education is education respecting differences. Multicultural education always creates structure and process in which every culture can express (Mughni, 2006: 98). From those definitions, it can be concluded that multicultural education is education respecting difference and teaching tolerance among society to create a piece in social society relationship.

While multicultural society is society that could emphasize himself as arbiter. It is as mediator in the reconciliation process when dialectic meets its bored. It is impossible for the society to not have problem all the time. Therefore, in this condition the dynamic of life moves. Multicultural society is society which has optimism to solve the problems. Optimism is not without capital, but optimism is supported by the ability and willingness to improve intellectual smartness, emotional, spiritual to own sensibility, appreciation, sympathy and empathy. The multicultural society is who has been occupying culture effectively, fast, clearly and ideally in the interaction and communication with other people (Liweri, 2003: 16)

The opponent of multicultural education is monoculture education. Its system will not only cause marginalization nondominant culture, but also will grow sensitivity towards the difference. Meanwhile the development of society leads to diversity of culture, social background, political choice, economic status, language even certain ethnicity (Maliki, 2010: 254) 
a. Multicultural Education Concept in Islamic Perspective

1) Multicultural Education Concept based on al-Quran

We need to muse some lessons said Allah through his messengers found in al-Quran. We need to optimize religion role as integration and unifier factor. al-Quran, for the example, there are some verses which can be based to respect and reconsolidate between human being, as stepping to do fair and wise in understanding the difference.

a. al-Hujurot, verse: 13

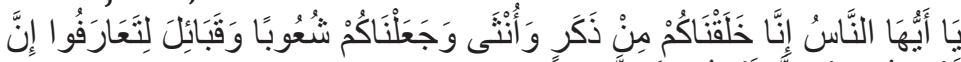

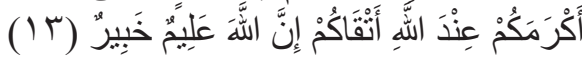

"O mankind! Lo! We have created you male and female, and have made you nations and tribes that ye may know one another. Lo! the noblest of you, in the sight of Allah, is the best in conduct. Lo! Allah is Knower, Aware."

b. al-Baqoroh, verse 148:

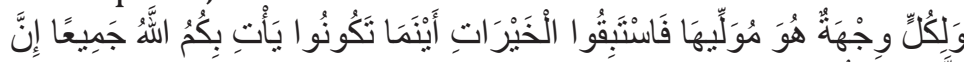

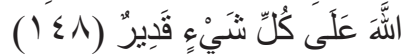

"And each one hath a goal toward which he turneth; so vie with one another in good works. Wheresoever ye may be, Allah will bring you all together. Lo! Allah is Able to do all things".

c. Al-Maidah, verse 48:

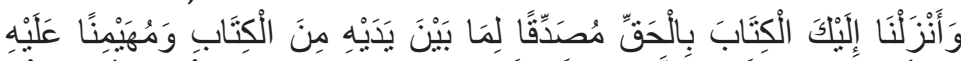

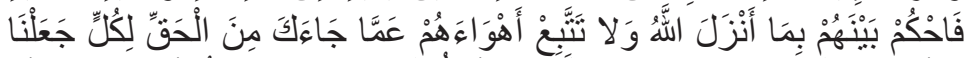

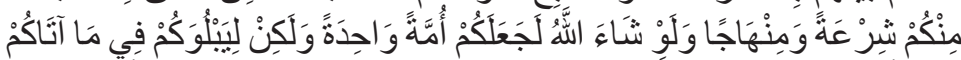

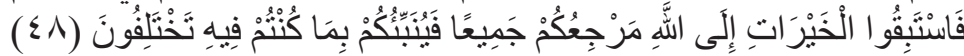

"And unto thee have We revealed the Scripture with the truth, confirming whatever Scripture was before it, and a watcher over it. So judge between them by that which Allah hath revealed, and follow not their desires away from the truth which hath come unto thee. For each We have appointed a divine law and a traced out way. Had 
Allah willed He could have made you one community. But that He may try you by that which He hath given you (He hath made you as ye are). So vie one with another in good works. Unto Allah ye will all return, and He will then inform you of that wherein ye differ".

d. Ali 'Imran, verse 103 :

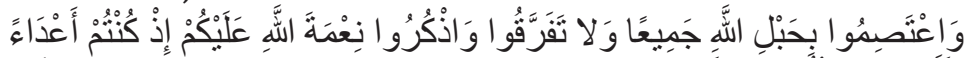

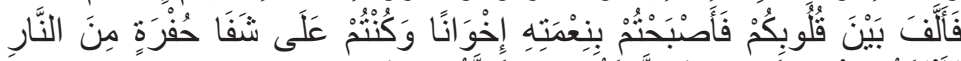

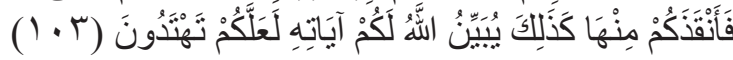

"And hold fast, all of you together, to the cable of Allah, and do not separate. And remember Allah's favor unto you: how ye were enemies and He made friendship between your hearts so that ye became as brothers by His grace; and (how) ye were upon the brink of an abyss of fire, and He did save you from it. Thus Allah maketh clear His revelations unto you, that haply ye may be guided".

Too much love for the embraced religion is a sign of religion figure failure in how to ground religion in various social lives, either in the nurture or culture diversity. When religion embracer has grown belief that his religion is the right one and there is no explanation that everyone has the same right to say that his religion is the right one too. This will become a problem that can make religions feuding and chiding each other. Islam recognizes differences, so the existing differences are supposed to be beauty and diversity in living in a society.

2) The concept of multicultural education based on Hadits

If we search from several hadits, we will fine multicultural education footing in madina charter history. This charter become reference for tribe and religion in that time live in a society. This charter also become charter for people who wants to explain government system and Islamic constitutional.

Multicultural footing can be tracked from Rasulullah SAW moral and personality. He is multicultural human being. 
He truly respects human right and highly honor difference. This is based on two reasons; first, Medina charter was proposed by Rasulullah as a reference of life supported by Madaniyah verses. Second, an explanation which states that Rasululloh's moral is al-quran. It means that both reasons affirms multicultural education footing in Islam is al-Quran and Rosulullah attitude (Azra, 2000: 13-14).

Tolerance embodiment shown by Rosulullah was when he sat with his friends and saw the crowd of musrikin entombing a kafir and Rosululloh stood and gave a tribute. From this history we can get a great message that is the feeling of respecting each other among human beings although with different belief or culture.

Explicitly, the word tolerance is not found in alQuran, but it's synonym, al-tasảmuh is found in Islamic prophetic tradition. The suitable word with the word root al-tasảmuh is found in hadits, inni ursitu bi al-hanafiyyat alsahmah. In other hadits said:

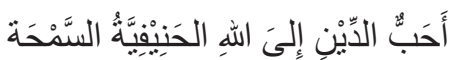

The most beloved religion by Allah is religion oriented at spirit of searching the right tolerantly and acceptably). In this context, as-samhah has linguistic affinity with tasâmuh or samâha, a modern Arabic terminology to refer at tolerance. This Muhammad's hadist is often used for Islamic reference some to support tolerance among other religions, where he was sent by Allah swt to teach that tolerance.

Rosululloh said "ikhtilafi ummati rahmatan" means that difference among my ummah is a grace. This hadits explains to us that difference is a certainty and it depends on how we address and make it as diversity that makes beautiful in society. 
b. Multicultural education urgency in Indonesia based on social and political survey

Multicultural education becomes special attention for government. It is proved in article 4 UU No 202003 about national education system. This article explains that education is held democratically without any discrimination by upholding human right, religious value, cultural value, and country plurality. Referring to UU Sisdiknas, the purpose of multicultural education is embedding sympathy, respect, appreciation, and empathy through religion embracers and different culture.

In UU No.20/2003 article 50 verse 3 about Sisdiknas that mandates the establishment of international schools which is often called RSBI or SBI that says: "central government and or local government hold at least one united education at all education level to be developed to be international school level". With this rule, central government or local government coordinate to create and develops at least at one united education in all education level to be managed and made to be school with international level.

The existing of international school got pro and contra. Who was pro of SBI said that education should be standardized to be measured and known by its education. Meanwhile who was contra said that the existing of SBI contradict with UUD 1945 that mandate all citizens have right to get decent education. Therefore it is not appropriate to hold RSSN, SSN, RSBI and SBI. Because the right to get education is not only owned by rich people, but for all citizens.

Multicultural education is a concept created with a purpose to create similar education opportunity for all Indonesian citizens. One of purposes of multicultural education concept is to build knowledge construction, attitude, and ability of students to contribute in pluralistic democratic society. These knowledge construction, attitude, and ability are needed by students to interact and communicate in plural society.

In the case of SBI we can take lesson that multicultural 
in the social aspect and policy are supposed to be fair. Every citizen has the same right in getting education and its for all citizens from different social background. In the basic laws which mandate SBI, seems deny the local culture and uphold the culture from outside of Indonesia. One of the factors is using English language in the teaching learning process of SBI.

1. The Diversity of Indonesian Culture

The word "culture" in Indonesian big dictionary means as thought, attitude, or customs. Based on structure, the meaning of culture is from culture tending to human thought. The culture is also meant everything related to human thought then it can relates to mind set, attitude, and physical work by a group of human being (Suharso, 2005: 78).

Though cultures definitions are various, there is a similarity which can be concluded. It can be identified from its characteristics. Culture has special character. First, it is general and specific. General means every human being in the world has culture, and specific means every culture owned by a certain group of citizen are diverse from one and another culture (Naim, 2011: 123).

Culture diversity is potentially to be conflict. Local culture diversity also enriches the value of culture and it can be capital to create multicultural Indonesia. In other hand this condition is very potential to break the society, to arise conflict among them, and social jelous. That problem will appear, if there is no good communication among local cultures. If there is no good understanding at other a group of culture, this can arise conflict. The conflicts have been happening in indonesia caused by ethnic, religion and interest. For the example Sampit history. This diversity can be used by povokator to make it as issue to arouse problem (Assegaf, 2004: 115).

To anticipate the problem, the existing diversity should be recognized as reasonable things. Then, it is 
needed a conflict management so the conflict potency can be controlled earlier to solve the problems, including multicultural education. The existence of multicultural education is hoped by every citizen to know, understand, appreciate, and communicate each other (Gunawan, 2000: 54-55)

One of government efforts to unite several cultures in Indonesia. They are: peaceful culture in 2000 has been declared as international peaceful culture year and the decade of 2001-2010 also has been declared as international decade of peaceful culture without any violence toward the children in the world. In the declaration of peaceful culture it is said that general meeting of $\mathrm{PBB}$ recognize peaceful as not only to remove violence and conflict, moreover peaceful need positive condition, dynamic involvement process which can be supported by dialogue. Meanwhile, conflict is solved by a condition where people can understand and work together (Zuhdi, 2008: 186).

Society, as said by Ary H. Gunawan, has function as culture successor from generation to the next generation. This process goes dynamically, suit to the situation, condition and society need. Media for over culture is education and social interaction. In this case, education can be defined as socialization process, socialize about value of knowledge, attitude, and creativity among generations.

Sutan Takdir Alisjahbana explain that there are six value or moral system in every human, social group, culture, and every social group consist of theoretical, economy, religion, esthetic power and brotherhood. Modern culture or civilization describes progressive culture, which the moral system is dominated by theoretical value aiming at identifying object and event objectively, and the economical value aiming at creating efficient objects.

After being attacked by reformism and democracy, Indonesia faced by many new challenges which are very 
complex. One of them is culture. In this culture, the occurrence of power displacement from central to local bring big impact toward local culture and its diversity recognition. When the moment of new reformation, the related policy to the culture was still in centralized but not for now.

Culture is one of country richness. It is no longer controlled by central policy, but it is developed in each local culture context. When something touch power, then there are several things can be utilized to seize authority or elongate that authority, including local issue inside.

2. Multicultural Education in the Diversity of National Culture

a. Multicultural Education in Indonesia

The condition of national multiculturalism can be figured out as double gem sword; one side is modality which can produce positive energy but in other side, when the diversity is uncontrollable, it will be destructive explosion that can damage structure and national principles. Human is created in the diversity of culture, therefore the development of human being should pay attention to that culture diversity (Mahfud, 2006: 80). In the context of Indonesian, so it becomes inevitability that human development should be based on multiculturalism. Remembering the truth that this country is build on multiculturalism.

Crisis of culture social can extends and be watched in any disoriented and dislocated in our society, for the example: disintegration of social politic which almost over; the disappear of social temper in facing life reality is getting herder so it is easy to do violence and anarchy, decrease of law respect, ethic, moral, and social politeness (Mahfud, 2006: 81).

Social change happens because it has been planned, the time or the cost, the humans and 
etcetera. Meanwhile, there is social change which is unplanned, like colonialism, or disasters and etcetera (Hasan, 2005: 42).

Multicultural education management cannot be released from the effort to chose at perspective of management in cultural pluralism existing in the society. There are two perspective theoretically. First, convessionalism approach which recognize the identity of cultural diversity. Second, deconvessionalism perspective which should be the regulation of ascriptive symbols management in public area. Symbols and signs representing identity or particular culture should not be brought to the public area. In the interaction to the public, it is only allowed to use sign and symbols together. Unity concept then distructure in uniform or known by unity without diversity (Maliki, 2010: 263).

Pancasila as the foundation of national culture is supposed to be owned by our country. It should be internalized in our life, should be in the soul of our self. The mistake is Pancasila only becomes verbal culture, so that Pancasila only stays verbally, not becomes identity of our country, and not becomes part of our culture (Djohar, 2006: 126).

Multicultural education tries to replace monoculture perspective. Multicultural education invites to see the difference naturally. Multicultural education give birth ready human beings to interact, corporate, respect each other, although the society life way and economic social status are different from each other (Maliki, 2010: 254).

The old order government chose convessionalism in the first. Government admits the ethnic diversity and society cultural diversity. To avoid conflict among cultural and ethnic identity, especially 
among indigenous and non indigenous, in $1950^{\text {th }}$ government limit the entrepreneurship and residence of non indigenous in the cities. The limitation only apply at china ethnic which is recognized as non indigenous by the country. New order government chose deconvessionalism by uniformity for national unity and integrity which actually is not more than efforts to handle the whole society.

Management system of cultural identity changed after reformation. In this moment, a nation is in stateless. Our nation is fragile, no longer authoritarian, because the micro economical policy made mistakes and caused moniter policy, so the country does not have what so called by the state capacity in managing the difference of cultural identity. This country let the society bring particular identity symbols and askcribtive to public area. What comes next is the emergence of some prejudices and conflict among ethnics. The indigenous request their right necessarily and the conflicts happened, like Sambas, Aceh and Ambon cases (Maliki, 2010: 264).

Recently, what happens is far from human hope that uphold social, harmonium, safety, peaceful, and brotherhood. In other words, discrimination, conflict, religious social, political crisis, economy, culture and education, getting wider in this country.

b. Kinds of Tribe and Cultural Diversity in Indonesia.

It is about last four years after reformation, noted that communal conflict or violence force toward minority group is happening more often. There are some factors cause it happens, for the examples cultural diversity which is added by the freedom to express. After reformation turns and the society given a space to develop their potency and local potency. So appear new culture which enrich Indonesian cultural diversity. 
Indonesia is a country which consist of thousands island and various cultural tribes. There are some tribes which stay in some areas in this country. Every tribe has its own diversity and different cultures.

1) The tribes in Indonesia

a. Sumatra Island.

Although it is only few citizen live in Sumatra Island compared to Java Island, but the tribes are developing. The Sumatra tribes are Aceh, Batak, Gayo, Komering, Mentawai.

b. Java Island

The number of citizen in this island is the most widely compared to other islands. We can find several tribes in this island, they are Java, Badui, Betawi, Bawean, Tengger, Sunda.

c. Kalimantan Island.

Kalimantan Island is one islands in Indonesia which has extraordinary natural wealth. There are many source of energy contained in the soil of Kalimantan island, also the diversity of tribes. The tribes in Kalimantan are Dayak, Pontianak, Limbai, Bawo, Kutai, Tunjung, and Bakung tribe.

d. Bali and Nusa Tenggara Island.

One of international or local tourist favorite destination is Dewata and North Nusa Island. Besides they have exotic attraction, they also have culture, custom, and unique tribe. In these both islands found some tribes, they are; Bali, Kore, Sumbawa, Sasak, and Flores.

e. Sulawesi Island.

Sulawesi is one of areas in Indonesia left behind from some sides of life compared to other areas. Although the citizens are left behind, they live peacefully in tribes and races diversity. The tribes in Sulawesi islands are Gorontalo, Sangir, Minahasa, Bajau, Makasar. 
f. Maluku Island.

In Maluku are found some developing tribes and ethnics. They often get conflict between one and another, though the conflict among tribes is not really can be found nowadays, still it needs to be kept. The tribes in Maluku island are Buru, Aru, Ambon, Pagu, Ternate, Tidore and Seram.

g. Irian Jaya Island.

Irian Jaya island is a rich natural wealth island. Gold mine Freeport is a prove of it. Irian jaya also has some tribes, they are Asmat, Aero, Gebe, Sawung, Sentani, Sawuy, Dani, and many more.

What is the relevancy of multiculturalism to us as Muslim and Indonesian people? First, our reality as a nation with full of diversity. De facto, Indonesia is spread in 17.000 islands more and consists of twentieth ethnics with different language, tradition, and reigion. De jure, we actually adopted the spirit of multiculturalism though the actualization is still weak. Pancasila and UUD 1945 tried to handle up the diversity, like curved firmly in the symbols of (Garuda) Indonesia in the words Binneka Tunggal Ika. "berbeda-beda tetapi tetap satu" which means different but remains the one, is a suitable motto to conclude the principles of multiculturalism. Unfortunately, we are stuck in the slogan and weak in action, then the multiculturalism felt strange or even suspected.

Tribe and culture diversity existing in Indonesia is one of evident where our country has lots of extraordinary wealth. Even though there are lots of tribes and culture, the social interaction among citizens remains good. Indonesian society generally use pancasila principles in addressing the differences. Keep respecting and upholding the differences will make peaceful and harmonic life although in the diversity of cultures. 
c. The solution to overcome the conflict of cultural diversity in Indonesia

Religion becomes one of factors that trigger conflict. It is needed to explain more about religion to society in order not to make misunderstanding among religion embracers. Because involving religion in conflict problem is contradictive with the religion lesson its self. In Islamic religion, for the example, the spirit that brought as has been said in Al Quran is moral aspek where the point is at monotheism and social fairness (Rahman, 1987: 49). It is not far different with the opinion of Harun Nasution which says that Islamic teaching about maximal worship to increase faith that formed in good attitude. Islam wants to teach human beings how to be good creature and stay away from badness and evil (Nasution, 1979: 53).

Religion will never be separated from social life, because religion itself is social reality in the construction context of embracer. Even though ontologically, it is sourced from single reality, the next development is religion becomes psychological, cultural, and social identity symptoms. In this context there will be three possibilities. First, religion can do penetration to social life and culture. Second, religion is influenced by external factors. Third, the dialectic between diversity and pluralism becomes definite things when religion was constructed by the embracer. This point is the start of a conflict can happens by the name of religion (Arifin, 2001: 67)

The purpose of studying about religion, besides it is not only led to the importance of "congregation" but also need to be led to reach national purpose in order to strengthen the principals of concord among religious communities in order to foster dynamic national stability and integrity. Studying religion in formal or informal education is led to the fundamental strategies as follow (Ismail, 2003: 157). 
When Islam is analyzed deeply, Islam will be known as very friendly and respective to the diversity as reality. In this case, the concept of rahmatan lil'alamin is the cultural basic of Islamic lesson. To run this humanity mission, Islam has instrument that is putting education as the priority. The education directly deals with the citizens. In the process of education, there is a process of transferring the value and knowledge to produce students with faith and knowledge. That concept should be understood as open, moreover in the religious pluralism like we have now. So it will not be impressed as exclusive and discriminative to human being.

\section{Conclusion}

Cultural diversity shows the existing vision and system of different life view. So the cultures need other culture. By learning other culture, it will open our horizon of understanding multiculturalism, so the difference of every culture can strengthen and contribute in the development of a country. Remembering the urgency of understanding multiculturalism in developing nation, then it is needed to manifest it concretely. We need to spread understanding and teach society about the urgency of multiculturalism which can bring Indonesia to the justice, prosperity and wealthy.

By running the principle of multiculturalism activity becomes an ideology which is recognized to solve any problems related with multiculturalism. So the society will not be too fanatic in defining the differences, especially cultural differences in Indonesia.

Every culture internally is plural, so continuous dialogue is really needed for the sake of unity. In multiculturalism society like Indonesia, dialogue paradigm relationship or reciprocal understanding is really needed to overcome negative access from a problem of national disintegration. Paradigm of reciprocal relationship in multiculturalism society socialize three normative 
competencies, they are cultural, social, and personal competency.

In education is supposed to be prepared the materials or curriculum to uphold the different of culture. Preparing curriculum that study about other culture from other tribe from traditional dance, literature, craft product, and etcetera.

Multiculturalism education equalization for the schools of both government and private even for the international schools which have their own curriculum referring to another country curriculum. Multiculturalism education equalization for all society levels without seeing their social background. 


\section{REFERENCES}

Assegaf, Abdurahman. 2004. Pendidikan Tanpa Kekerasan, Tipologi Kondisi, Kasus Dan Konsep. Yogyakarta: Tiara Wacana.

Arifin, Syamsul. 2001. Menambah Jalan Baru Dalam Beragama Rekonstruksi kearifan Perenial Agama dalam masyarakat Madani dan Pluralitas Bangsa, cet. 2. Yogyakarta: Ittaqa Press.

Djohar MS. 2006.Pengembangan Pendidikan Nasional Menyongsong Masa Depan. Yogyakarta:Gravika Indah.

Gunawan, Ary H. 2000. Sosiologi Pendidikan, Suatu Analisa Tentang Pelbagai Problem Pendidikan. Jakarta: Rineka Cipta.

Hasan, Mohammad Tholchah. 2000. Islam Dalam Perspektif Sosio Kultural, cet 2. Jakarta: Lantabora Pres.

Hilmy. 2003. Menggagas Paradigma Pendidikan Berbasis Multikulturalisme Jurnal Ulumuna.Mataram: STAIN. Vol. VII. Edisi 12. No. 12 (Juli-Desember)

Ismail, Faisal. 2003. Ketegangan Kreatif Peradaban Islam Idealisme Versus Realisme. Jakarta: PT Bakti Aksara Persada.

Liweri, Alo. 2003. Makna Budaya Dalam Komunikasi Antar Budaya. Yogyakarta: LkiS.

Maliki, Zainudin. 2010. Sosiologi Pendidikan. Yogyakarta: Gadjah Mada University Press,

Mughni, Syafiq A. 2006. Pendidikan Berbasis Multikulturalisme, kata pengantar dalam Choirul Mahfud, Pendidikan Multikultural. Yogyakarta: Pustaka Pelajar.

Mahfud, Choirul. 2006. Pendidikan Multikultural. Yogyakarta: Pustaka Belajar.

Naim, Ngainum dan Ahmad Sauqi. 2011. Pendidikan Multikultural Konsep dan Aplikasi. Yogyakarta: Arruz Media.

Nasution, Harun. 1979. Islam Ditinjau Dari berbagai Aspeknya, Jilid 
I. Jakarta: UI Press.

Rahman, Fazlur. 1987. Islam. Penerjemah Senoaji Saleh. Jakarta: Bina Aksara.

Suharso dan Ana Retnoningsih. 2005. Kamus Besar Bahasa Indonesia. Semarang: Widya Karya.

Sukardi, Imam. Paradigma Pendidikan Multikultural Diperguan Tinggi, di akses tanggal 6 Oktober 2013

Zuhdi, Darmiyati. 2008. Humanisasi Pendidikan. Jakarta: Bumi Aksara. 